\title{
Range extension of Cavia tschudii Fitzinger, 1867 (Mammalia: Caviidae) and first record in Catamarca, northwestern
} Argentina

\author{
Pablo E. Ortiz ${ }^{1^{*}}$ and J. Pablo Jayat ${ }^{2}$ \\ 1 Instituto Superior de Correlación Geológica (INSUGEO), Consejo Nacional de Investigaciones Científicas y Tecnológicas (CONICET), Miguel Lillo \\ 205, 4000. San Miguel de Tucumán, Argentina. \\ 2 Universidad Nacional de Chilecito, Instituto de Ambientes de Montaña y Regiones Áridas (IAMRA). Ruta Los Peregrinos s/n, CP F5360CKB. \\ Chilecito, La Rioja, Argentina. \\ * Corresponding author. E-mail: peortiz@uolsinectis.com.ar
}

\begin{abstract}
We report the first record of the genus Cavia and the species Cavia tschudii (Rodentia, Caviidae) in Catamarca province, northwestern Argentina, which represents a range extension of about $110 \mathrm{~km}$ southward for the species. The cranial and dental remains were recovered from an owl pellet sample found in eastern slopes of the Ambato range, at 1600 $m$ elevation, in a highland grasslands-Chaco Serrano ecotone. According to the environmental continuity along the Ambato range, we suggest that the presence of $C$. tschudii in southernmost Catamarca and northern La Rioja province is likely.
\end{abstract}

Cavia tschudii Fitzinger, 1867 is a small caviomorph rodent broadly distributed through the Central Andean region, from northern Peru to northwestern Argentina (Woods and Kilpatrick 2005). Within Argentina the species is known from only a small number of records despite intensive sampling efforts carried out for many years (Ortiz 2003). In this note we report a new collection locality for Cavia tschudii that extends its southern distribution and adds the species to the mammal fauna of an additional political province. The studied material was recovered through the analysis of an owl pellet sample collected below a cliff beside the Highway 4, $10 \mathrm{~km}$ south of El Rodeo (28¹8'39" S, 6553'54" W, 1580 m elevation), Catamarca province, Argentina (Figure 1). The remains were identified using diagnostic characters from the literature (Tonni 1984; Ortiz 2003) and by comparison with reference material housed at the Colección de Mamíferos Lillo (CML), the Colección de Paleontología de Vertebrados Lillo, and the Colección de Material de Egagrópilas del Instituto Superior de Correlación Geológica, San Miguel de Tucumán, Argentina. The specimens collected are preserved in this last collection under the number CEI 999.

All the examined remains (three maxillae and two mandibles, referable to two individuals) are referred to Cavia tschudii based on cranial and dental morphology (Figure 2) and morphometric values. Representatives of the genus Cavia are clearly differentiated from other genera of Caviinae through the different occlusal morphology of molars, including the presence of cement filled interlaminar folds. Two species of Cavia are known to occur in Argentina, C. tschudii and C. aperea. The remains of Cavia tschudii here studied are distinguished from C. aperea, by the following combination of characters: general size clearly smaller; anterior region of zygomatic arches more delicate; posterior margin of incisive foramina closer to the alveoli of P4; palate shorter, with the anterior margin of mesopterygoid fossa extending to the level of the first lamina of M3; coronoid apophysis poorly developed; narrower expansion of the masseteric crest and shallower masseteric fossa; sigmoid notch defined by two sharp ridges that delimit a plane area between them.

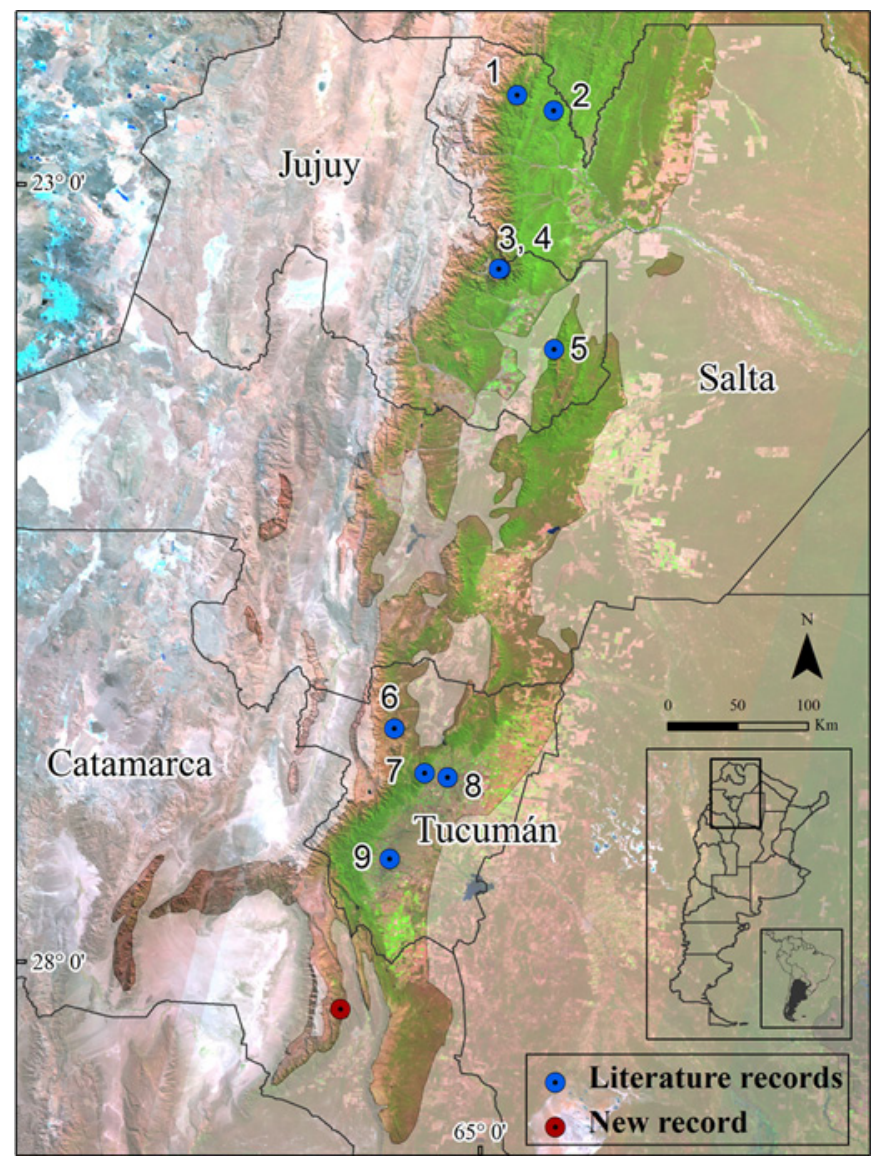

FIgURE 1. Collection localities for Cavia tschudii in northwestern Argentina. Unshaded area corresponds to the Yungas ecoregion. Blue dots: records obtained from the literature; red dots: new record. 1, Parque Nacional Baritú, Río Lipeo; 2, Angosto del Río Pescado, 650 m; 3, Cerro Calilegua, El Duraznillo, 3000 m; 4, Duraznillar, 2500 m; 5, 5 km E of El Palmar, 794 m; 6, Ñorco, Vipos, 2500 m; 7, San Javier; 8, San Miguel de Tucumán; 9, Concepción. 
Cavia tschudii has been cited in the following Argentine localities: Jujuy Province: $5 \mathrm{~km}$ E of El Palmar, $794 \mathrm{~m}$ (2404' S, 64³2' W; Dunnum and Salazar-Bravo 2010), Cerro Calilegua, El Duraznillo, 3000 m (2333' S, 6452' W; Ortiz 2003; Díaz and Barquez 2007), Duraznillar, $2500 \mathrm{~m}$ (2334' S, 6453' W; Heinonen and Bosso 1994), Mountains W of Yala (not precisely located; Díaz and Barquez 2007); Salta Province: Angosto del Río Pescado, 650 m (22³3' S, 64²' W; Gil and Heinonen Fortabat 2003), Parque Nacional Baritú (not precisely located; Díaz et al. 2000), Parque Nacional Baritú, Río Lipeo (22²7’ S, 6446’ W; Díaz et al. 2000); Tucumán Province: Concepción (27²1' S, 65³5’ W; Tonni 1984; Ortiz 2003), Ñorco, Vipos, $2500 \mathrm{~m}$ (26³0' S, 65³3' W; Thomas 1926; Ortiz 2003), San Javier

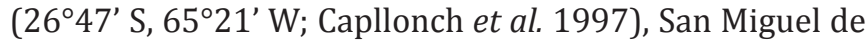
Tucumán (2649' S, 65²12' W; Soncini et al. 1985) (Figure 1).

All modern records of Cavia tschudii in Argentina come from Yungas environments, from humid forest at $400 \mathrm{~m}$ to highland grasslands at $3000 \mathrm{~m}$ elevation (Ortiz 2003). Although intensive samplings were carried out in different localities and environments, very few specimens have been captured in the last decades. Similarly, despite the examination of about a hundred owl pellet samples in the last twenty years, the specimens presented here are just the second recovered in northwestern Argentina. The evidence of trapping and pellet analysis indicates that Cavia tschudii is extremely rare in the southern portion of their range in Argentina.

The new record of Cavia tschudii comes from an area of highland grasslands of Yungas, in ecotone with Chaco Serrano woodlands that reach 1500 meters elevation in humid ravines. Patches of these two environments are included within the owl's feeding range, estimated in 5 $\mathrm{km}$. In the same sample we registered several other small mammal species frequently trapped in this area, including Akodon spegazzinii, Necromys sp., Oligoryzomys brendae, Oligoryzomys cf. O. flavescens, Calomys musculinus, Phyllotis osilae, Andinomys edax, Galea leucoblephara, Ctenomys sp., and Thylamys sp. The new locality extends the range of the species at least $110 \mathrm{~km}$ to the south, adding the genus Cavia for Catamarca province (see Ojeda 2006). According to the topographic and environmental continuity along the

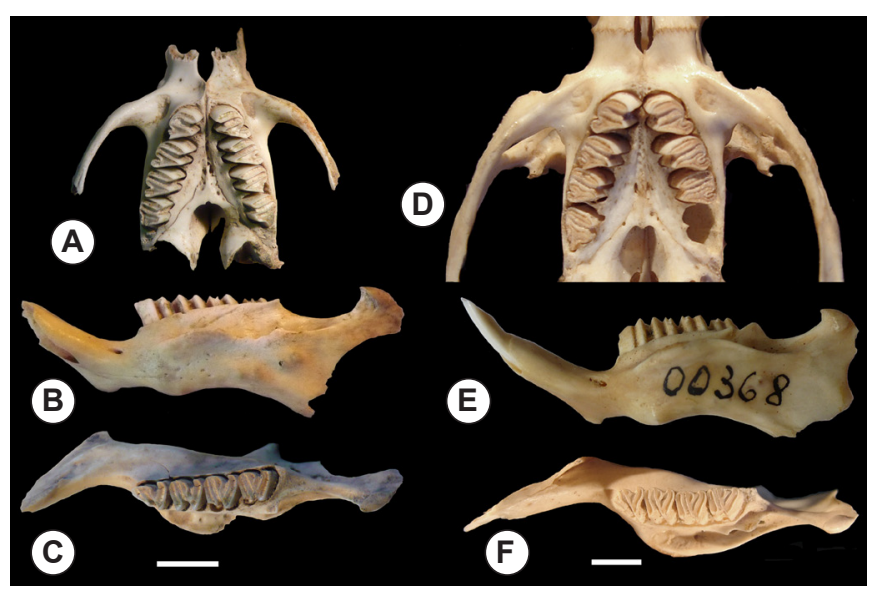

Figure 2. Remains of Cavia tschudii from $10 \mathrm{~km} \mathrm{~S}$ of El Rodeo on Hwy 4 (Catamarca province, Argentina) compared to Cavia aperea specimens. A, B, and C: Cavia tschudii (CEI 99-9). D, E, and F: Cavia aperea (D, CML 8404, Boca del Río, Buenos Aires province, Argentina; E and F, CML 368, Las Talas, Buenos Aires province, Argentina). Scale bar $=5 \mathrm{~mm}$.
Ambato range, the presence of $C$. tschudii in southernmost Catamarca and northern La Rioja province (Chumbicha, Otro Cerro, and Cuesta de la Cébila area) seems probable. Other rodents primarily associated to Yungas environments have recently been recorded further south in more xeric habitats of Monte de Sierras y Bolsones (e.g., Akodon spegazzinii [Jayat et al. 2010], A. simulator [Jayat and Ortiz unpublished data], Oligoryzomys brendae [Teta et al. in prep.]), areas that could also be suitable for $C$. tschudii.

ACKNOWLEDGMENTS: We thank D. García López and R. González by their capable assistance in the field. Jon Dunnum and one anonymous reviewer provided useful comments on an earlier version of this manuscript. This paper was funded by the Consejo de Investigaciones de la Universidad Nacional de Tucumán (grant 26/G434 to P. E. Ortiz) and the Consejo Nacional de Investigaciones Científicas y Tecnológicas (CONICET). This work was possible thanks to the institutional support of the following institutions: Instituto de Ecología Regional-Laboratorio de Investigaciones Ecológicas de las Yungas (IER-LIEY); Instituto de Ambientes de Montaña y Regiones Áridas (IAMRA), Universidad Nacional de Chilecito; Instituto Superior de Correlación Geológica (INSUGEO-CONICET); and Cátedra de Paleontología, Universidad Nacional de Tucumán.

\section{Literature Cited}

Capllonch, P., A. Autino, M.M. Díaz, R.M. Barquez and M. Goytia. 1997. Los mamíferos del Parque Biológico Sierra de San Javier, Tucumán, Argentina: observaciones sobre su sistemática y distribución. Mastozoología Neotropical 4(1): 49-71.

Díaz, M.M. and R.M. Barquez. 2007. The wild mammals of Jujuy province, Argentina: systematics and distribution; p. 417-578 In D.A. Kelt, E.P. Lessa, J. Salazar-Bravo and J.L. Patton (ed.). The Quintessential Naturalist: Honoring the Life and Legacy of Oliver P. Pearson. University of California Publications in Zoology 134.

Díaz, M.M., J. Braun, M. Mares and R.M. Barquez. 2000. An update of the taxonomy, systematics, and distribution of the mammals of Salta Province, Argentina. Occasional Papers, Sam Noble Oklahoma Museum of Natural History 10: 1-52.

Dunnum, J.L. and J. Salazar-Bravo. 2010. Molecular systematics, taxonomy, and biogeography of the genus Cavia (Rodentia: Caviidae). Journal of Zoological Systematics and Evolutionary Research 48(4): 376-388.

Gil, G. and S. Heinonen Fortabat. 2003. Lista comentada de los mamíferos del Parque Nacional Baritú (Salta, Argentina). Acta Zoológica Lilloana 47(1-2): 117-135.

Heinonen Fortabat, S. and A. Bosso. 1994. Nuevos aportes para el conocimiento de la mastofauna del Parque Nacional Calilegua (Provincia de Jujuy, Argentina). Mastozoología Neotropical 1(1): 5160.

Jayat, J.P., P.E. Ortiz, U.F.J. Pardiñas, G. D’ Elía and J. Salazar-Bravo. 2010. The boliviensis group of Akodon (Rodentia: Cricetidae) in northwestern Argentina: species limits, distribution and the description of a new species. Zootaxa 2409: 1-61.

Ojeda, R.A. 2006. Familia Caviidae Waterhouse, 1839; p. 206-210 In R.M. Barquez, M.M. Díaz and R.A. Ojeda (ed.). Mamíferos de Argentina: sistemática y distribución. Mendoza: Sociedad Argentina para el Estudio de los Mamíferos.

Ortiz, P.E. 2003. Fossil record and distribution of Cavia tschudii (Caviidae, Rodentia) in Argentina. Mammalia 67(4): 607-611.

Soncini, R., H. Salas and L. Marcus. 1985. Alimentación de la lechuza de los campanarios (Tyto alba) en San Miguel de Tucumán. Historia Natural (Corrientes) 5: 49-54.

Thomas, 0. 1926. The Spedan Lewis South American exploration. 3. On mammals collected by Sr. Budin in the province of Tucumán. Annals and Magazine of Natural History (9)17: 602-609.

Tonni, E.P. 1984. The ocurrence of Cavia tschudii (Rodentia, Caviidae) in the Southwest of Salta Province, Argentina. Studies on Neotropical Fauna and Environment 19(3): 155-158.

Woods, C.A. and C.W. Kilpatrick. 2005. Infraorder Hystricognathi; p. 1538-1600 In D.E. Wilson and D.M. Reeder (eds.). Mammal species of the world: A taxonomic and geographic reference. Third edition. Baltimore: Johns Hopkins University Press.

RECEIVED: December 2011

ACCEPTED: June 2012

Published ONLine: August 2012

EDITORIAL RESPONSIBILITY: Marcelo Passamani 